\title{
The Study of External Signs, Microscopy and Chemical Composition of Medicinal Plant Materials of Veronica beccabunga L. Herb
}

\author{
Angelina V Strelyaeva, Olga A Larina*, Alla M Antsyshkina, Roman M Kuznetsov, Alina A Bondar, Vladimir A \\ Sorokin
}

Angelina V Strelyaeva, Olga A

Larina*, Alla M Antsyshkina,

Roman M Kuznetsov, Alina A

Bondar, Vladimir A Sorokin

I.M. Sechenov First Moscow State Medical University, Pharmaceutical Natural, Science Department Izmailovsky Boulevard, 8 , 105043, Moscow, RUSSIA.

\section{Correspondence}

\section{Olga A Larina}

I.M. Sechenov First Moscow State Medical University, Pharmaceutical Natural, Science Department Izmailovsky Boulevard, 8,

105043, Moscow, RUSSIA.

\section{E-mail: larina-olga.larina@yandex.ru}

History

- Submission Date: 23-12-2019;

- Review completed: 30-12-2019;

- Accepted Date: 16-01-2020.

DOI : 10.5530/pj.2020.12.61

Article Available online

http://www.phcogj.com/v12/i2

\section{Copyright}

(C) 2020 Phcogj.Com. This is an openaccess article distributed under the terms of the Creative Commons Attribution 4.0 International license.

\begin{abstract}
Introduction: Veronica beccabunga L. belongs to the class dicotyledons, order Lamiáles, family Scrophulariaceae. Representatives of the genus Veronica have long been used in folk medicine as antiinflammatory, antibacterial, antiseptic, wound healing, hemostatic, choleretic and antispasmodic drugs. Widely studied species are Veronica officinalis and Veronica chamaedrys. Veronica beccabunga $L$., which is the object of our study, remains a poorly studied plant. Aim: The study of external signs, microscopy and chemical composition of medicinal plant materials of Veronica beccabunga L. herb. Materials and Methods: Chromato-mass spectrometry was used in the work. Results and Discussion: When describing external signs and microscopy, diagnostic signs of Veronica beccabunga were revealed. 27 compounds were identified by chromatography-mass spectrometry. The maximum content falls on: Citronellol epoxide (R or S) (30.5\%), Linolenic acid, ethyl ester (15.18), Diethyl succinate (12.17\%), Ethyl palmitate (6.43\%), Phytol (4.89\%), Acetaldehyde ethyl amyl acetal (3.94\%), Dibenzylamine (3.01\%), Oleamide (2.77\%), 2-(1-Methylbutyl)oxirane (2.7\%), Butyl octyl phthalate(1.7\%), Ethyl 10-bromodecanoate (1.68), Valeric acid, 4-methyl-, ethyl ester (1.58). Glycoside detected : 1-Benzyl-1Hbenzimidazole 3-oxide (0.76\%). Conclusion: The revealed morphological and anatomical signs of Veronica beccabunga herb can be used to diagnose this species and develop authenticity indicators for promising medicinal herbs. 27 compounds were identified by chromatographymass spectrometry. Using the method of simple normalization, the relative percentage of identified compounds was determined.
\end{abstract}

Key words: Veronica beccabunga L., 1-Benzyl-1H-benzimidazole 3-oxide.

\section{INTRODUCTION}

Veronica beccabunga $L$. belongs to the class dicotyledons, order Lamiáles, family Scrophulariaceae. The scientific name of the genus Veronica dates back to antiquity and is already found in Roman and ancient Greek authors. B. N. Golovkin believes that the name Veronica was given in 1542 by the German botanist Leonart Fuchs (1501-1566) in honor of St. Veronica. ${ }^{1-19}$ Species numbers vary between two and fifteen with many subspecies. Veronica beccabunga $L$. is widespread. Western Europe: all countries south of $65^{\circ}$ north latitude. Asia: Turkey, China. North America: USA, Canada. On the territory of the former USSR it is found from the western border to the southern part of the Ural Range, in the Caucasus, in Siberia. In the north reaches the Karelian Isthmus, the southern coasts of Lake Ladoga and Onega, the confluence of Sukhona and Vychegda, in the region of Pechora, Arkhangelsk. It is found in Crimea. ${ }^{1}$

It grows along the banks of reservoirs, in streams, near springs, on key swamps, in places where groundwater emerges, i.e. is a hydrophyte (Figure $1 \mathrm{~A}, \mathrm{~B}){ }^{6,8,20}$ Representatives of the genus Veronica have long been used in folk medicine as antiinflammatory, antibacterial, antiseptic, wound healing, hemostatic, choleretic and antispasmodic drugs. ${ }^{14,17}$ Veronica beccabunga $L$. is a member of the semi-aquatic plants. Researchers mentioned this medicinal plant in their scientific work, conducting morphometric and molecular studies based on plastid and nuclear ribosomal DNA groups.

Further, flow cytometry has been used to reveal the ploidy level, especially of the Egyptian endemic taxa. ${ }^{9,13,15,16,18}$ In the medicinal herb Veronica, a number of authors have identified aucubin,catalpol, salidroside, gardoside, mussaenosidic acid, 8-epiloganic acid, arborescosidic acid and alpinoside. ${ }^{7,10,11,21,22}$ Widely studied species are Veronica officinalis and Veronica chamaedrys. Veronica beccabunga $L$., which is the object of our study, remains a poorly studied plant.

There is no description in the literature of the anatomical structure of autonomic organs and the chemical composition of this species has not been well studied. Therefore, the study of raw materials Veronica beccabunga $L$. with the aim of standardization is relevant.

\section{MATERIALS AND METHODS}

Several series of thin sections from the axial organs of the plant were made. Endoderm was also removed 
on both sides of the leaf. To avoid beveled sections, it is necessary to first align the surface to be cut by placing the razor strictly perpendicular to the longitudinal axis of the organ. All subsequent sections are made in the same direction. Slices and endoderm of the leaf were placed in Petri dish with water and selected three of the best, the thinnest, (transparent), and mowed (floating horizontally). Selected sections were placed on a glass slide in a drop of water and their suitability for work was checked. Suitable sections for work were treated with reagents. To do this, a drop of water is wet with filter paper from a glass slide, one of the sections is pushed to the side. Two sections were treated with phloroglucinol and concentrated sulfuric acid (a reagent for lignin), to identify cells with lignified walls, they turned red; one remaining section is chlorozinc-iodine to detect starch in the cells. After staining, the reagents are wetted with filter paper, a drop of water is applied to the sections, covered with a coverslip and placed under a microscope for a small increase. ${ }^{3}$ The preparations were carefully examined both at a small and at a large magnification of the microscope, tissues were recognized. These preparations were sketched, photographed and described.

The component composition of the samples was studied by gas chromatography-mass spectrometry. The study was carried out on an Agilent Technologies instrument, consisting of: 1) a 7890 gas chromatograph (HP-5 column, $50 \mathrm{~m} \times 320 \times 1.05 \mu \mathrm{m})$ and 2) a $5975 \mathrm{C}$ mass selective detector with a quadrupole mass analyzer.

Chromatography temperature program: at $40^{\circ} \mathrm{C}$ - isotherm $2 \mathrm{~min}$; further programmable heating to $250^{\circ} \mathrm{C}$ at a speed of $5^{\circ} \mathrm{C} / \mathrm{min}$; at $250^{\circ} \mathrm{C}$ - isotherm for $15 \mathrm{~min}$; further programmable heating to $320^{\circ}$ $\mathrm{C}$ at a rate of $25^{\circ} \mathrm{C} / \mathrm{min}$; at $320^{\circ} \mathrm{C}$ - isotherm $5 \mathrm{~min}$. Flow divider 1:50. The temperature of the injector is $250^{\circ} \mathrm{C}$. The temperature of the interface is $280^{\circ} \mathrm{C}$. The carrier gas is helium; flow rate $-1 \mathrm{ml} /$ min. Chromatogram of samples - total ion current. Mass spectrometric analysis conditions: energy of ionizing electrons $70 \mathrm{eV}$; registration of mass spectra in positive ions in the range $(\mathrm{m} / \mathrm{z})$ from 20 to 450 at a speed of 2.5 scans / sec. Software - ChemStation E 02.00., licensed. The identification of the component composition (qualitative analysis) was carried out using the library of complete mass spectra NIST-05 and the corresponding values of the chromatographic linear retention indices. The relative content (\%) of the components of the mixture (quantitative analysis) was calculated from the ratio of the areas of chromatographic peaks (by simple normalization).

\section{RESULTS AND DISCUSSION}

\section{External signs}

Whole raw materials. Whole or partially crushed leafy stems with or without flowers, less often with buds or fruits of various degrees of development, sometimes partially showered. Stems cut above brown bottom leaves, $10-50 \mathrm{~cm}$ long, up to $0.4 \mathrm{~cm}$ thick, ascending, rooting at the base, branched, usually bare, but sometimes slightly pubescent at the top. The leaves are opposite, rounded or oval, fleshy, with a blunt apex, finely serrated or with smooth edges, dark green, shiny, with short petioles. Flowers are collected 10-30 in loose sinus brushes, twice the size of the leaves and greatly elongated with the fruits. Calyx deeply four-divided into oblong-lanceolate acute lobes. The corolla is usually blue with blue stripes, 4-9 $\mathrm{mm}$ in diameter, with a very short tube, with a broad-ovoid upper lobe, ovate lateral and narrow-ovoid lower.

Stamens shorter than the corolla, with curved threads and large anthers. The fruits are almost spherical capsules, 3-4 mm long, strong, swollen, glabrous, with a very small notch or without a notch. Seeds are elliptical, about $0.5 \mathrm{~mm}$ long, including 20-30 in the nest. The color of the stems and leaves is green, the flowers are blue with blue stripes, the fruits are grayish-green. The smell is faint. The taste is bitter (Figure $2 \mathrm{~A}, \mathrm{~B}$ ).

\section{Ground raw materials}

Pieces of stems, leaves, parts of flowers and fruits passing through a sieve with holes with a diameter of $7 \mathrm{~mm}$. The color of the pieces of stems and leaves is green, the flowers are blue. The smell is faint. The taste is bitter (Figure 1C).

\section{Microscopic analysis}

When studying the anatomical structure of leaves, it was found that leaf blades have a dorsoventral structure. The cells of the upper epidermis of the leaf are less sinuous and larger than the cells of the lower epidermis. The stomata are amphistomatic; numerous, anomocytic (disordered), surrounded by 3-5 cells of the epidermis. The epidermis of the leaf is pubescent with capitate hairs with a bicellular head on a unicellular pedicle (Figure $3 \mathrm{~A}, \mathrm{~B}$ ).

No trichomes were found in the epidermis of the stem. In the primary cortex, aerenchyma (assimilation parenchyma) is well developed, which indicates the development of the plant under conditions of excessive moisture. A layer of large elongated cells of starchy endoderm is developed. Sclerenchyma is not expressed. Non-bunch type conductive system. Xylem vessels located in rows are clearly distinguishable (on average 5 vessels in a row, decreasing in diameter to the center). In the parenchyma of the core with a large increase, the presence of cells with brown contents was noted (Figure 3 C, D, E).

Rhizome also has a typical structure for rhizomes of dicotyledonous herbaceous plants. The integumentary tissue is represented by a cork (i.e., the rhizome is perennial). The primary cortex consists of a storage parenchyma represented by an aerenchyma and an endoderm layer. In aquatic plants, the aerenchyma performs not only the function of gas exchange. Air cavities in the stems and rhizome reduce the specific gravity of plants, allowing them to freely float in water. In the central axial cylinder, the conductive fabrics have a non-bundle structure. In the center is the core of the storage parenchyma. The presence of a core is a hallmark of the root (Figure $2 \mathrm{~F}$ ).

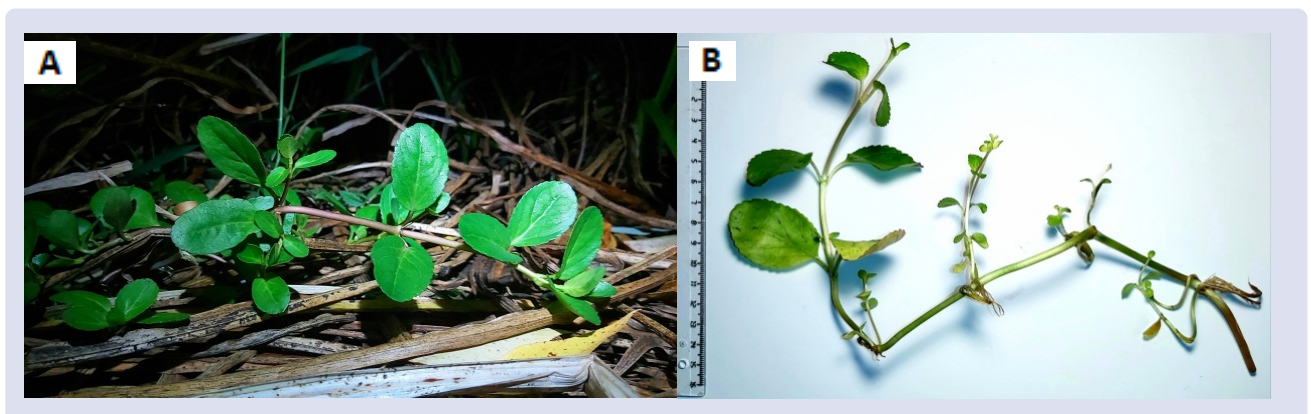

Figure 1: (A) Appearance of Veronica beccabunga L. in natural conditions. (B) Fresh herb Veronica beccabunga L. 
The method of chromatography-mass spectrometry was used to analyze the alcohol extraction obtained from the medicinal herb of Veronica beccabunga L. (Figure $4 \mathrm{~A}, \mathrm{~B}$ ). The alcoholic extract was prepared from the fresh herb Verónica beccabunga. The grass was crushed and filled with $95 \%$ alcohol in a ratio of 1: 5 . Insisted for 14 days and then filtered. A sample was injected into an Agilent Technologies instrument. 27 compounds were identified (Table 1).

The relative percentage of each component was calculated taking into account unidentified peaks (Diagram 1).

The maximum content falls on: Citronellol epoxide (R or S) (30.5\%), Linolenic acid, ethyl ester (15.18), Diethyl succinate (12.17\%), Ethyl palmitate (6.43\%), Phytol (4.89\%), Acetaldehyde ethyl amyl acetal
(3.94\%), Dibenzylamine (3.01\%), Oleamide (2.77\%), 2-(1-Methylbutyl) oxirane (2.7\%), Butyl octyl phthalate(1.7\%), Ethyl 10-bromodecanoate (1.68), Valeric acid, 4-methyl-, ethyl ester (1.58). Glycoside detected: 1-Benzyl-1H-benzimidazole 3-oxide (0.76\%) (Diagram 2). Other compounds also found :1-Methylbutyl acetate (1.2\%), Valeraldehyde, diethyl aceta (1.2\%), 2-Myristynoyl-glycinamide (1.09\%), Stearoylhydrazine (1.06\%), Butylaldehyde diethyl acetal (1.04\%), 3-Hydroxypropanoic acid hydrazide (0.91\%), Ethyl 5-[(methylamino) acetyl]-10,11-dihydro-5H-dibenzo[b,f]azepin-3-ylcarbamate $(0.84 \%)$, Hexadecanohydrazide $(0.83 \%)$, Benzyl carbazate $(0.79 \%)$, Propanoic acid, 3-hydroxy-, hydrazide (0.79\%), 5-Hydroxynorvaline $(0.76 \%)$, Oxamic acid hydrazide (0.74\%), Aminomocovina (0.70\%).

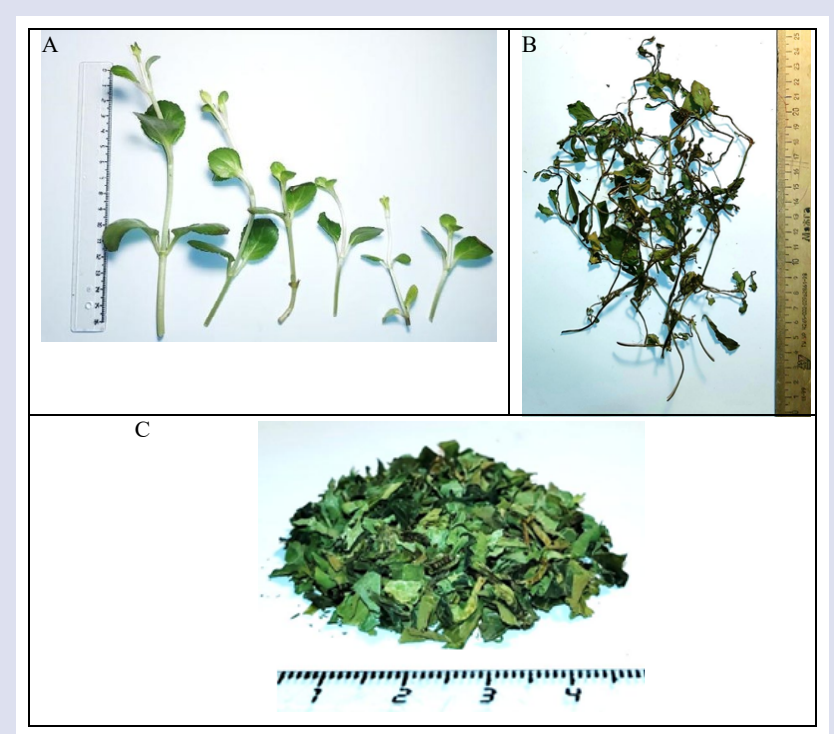

Figure 2: (A) Fresh of V. beccabunga, (B) dried of V. beccabunga, (C) ground raw materials.

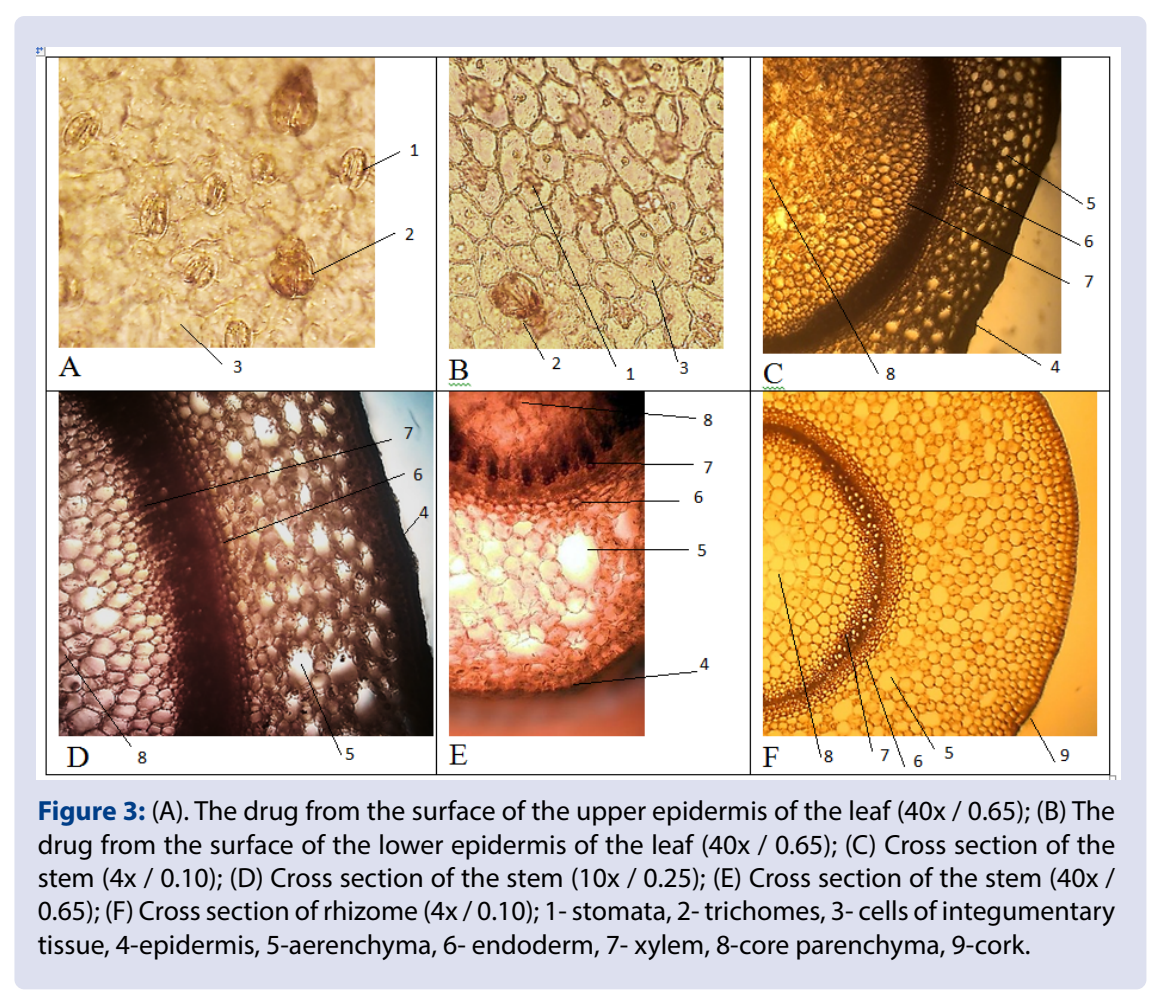




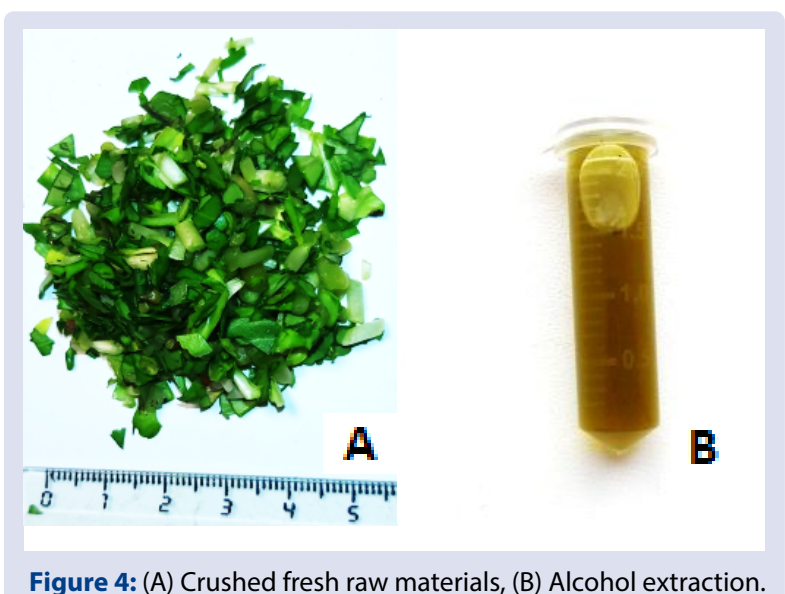

Figure 4: (A) Crushed fresh raw materials, (B) Alcohol extraction.

Table 1: The compounds identified in alcohol extraction from the Veronica beccabunga $L$.

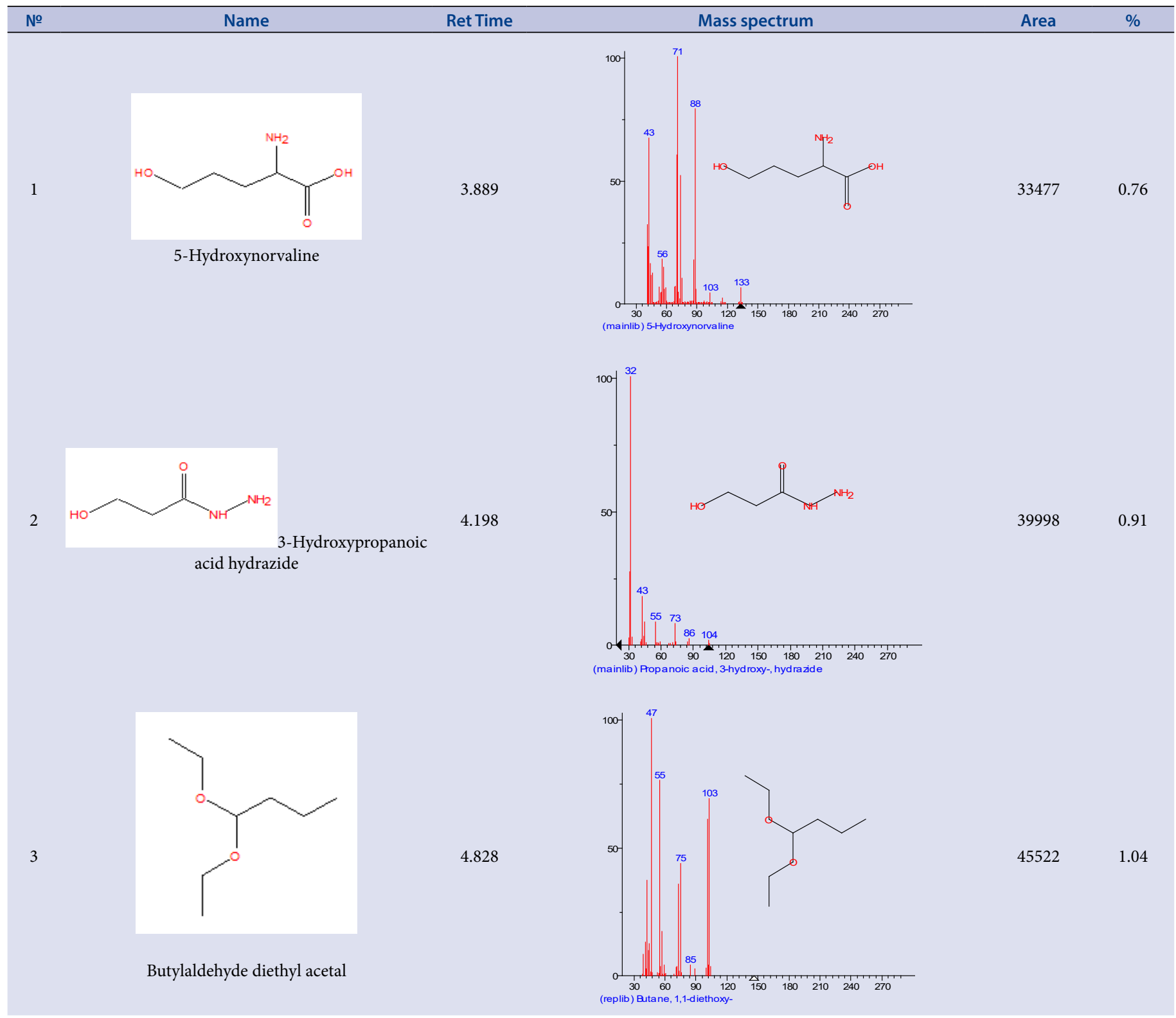


4

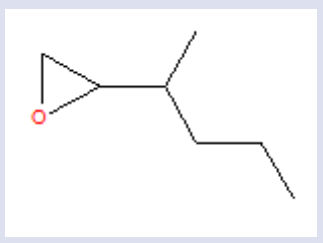

2-(1-Methylbutyl)oxirane

5

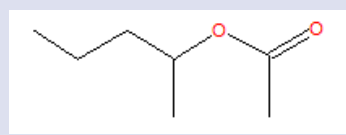

1-Methylbutyl acetate

6

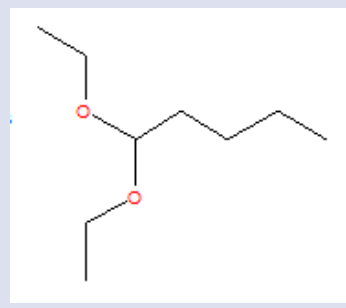

Valeraldehyde, diethyl aceta

7

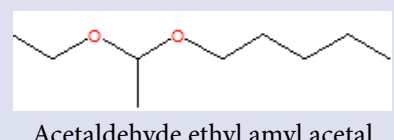

4.953

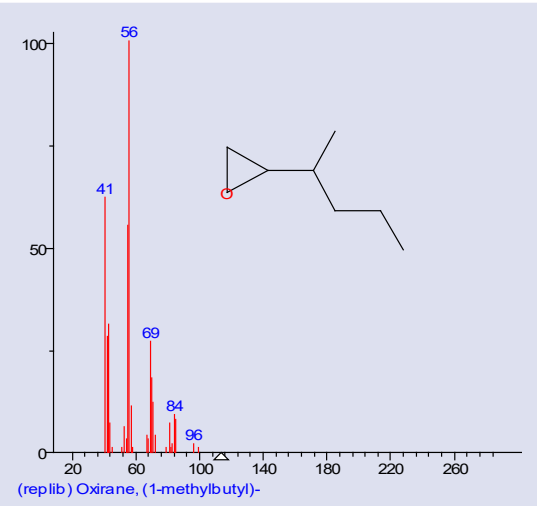

5.102

6.422
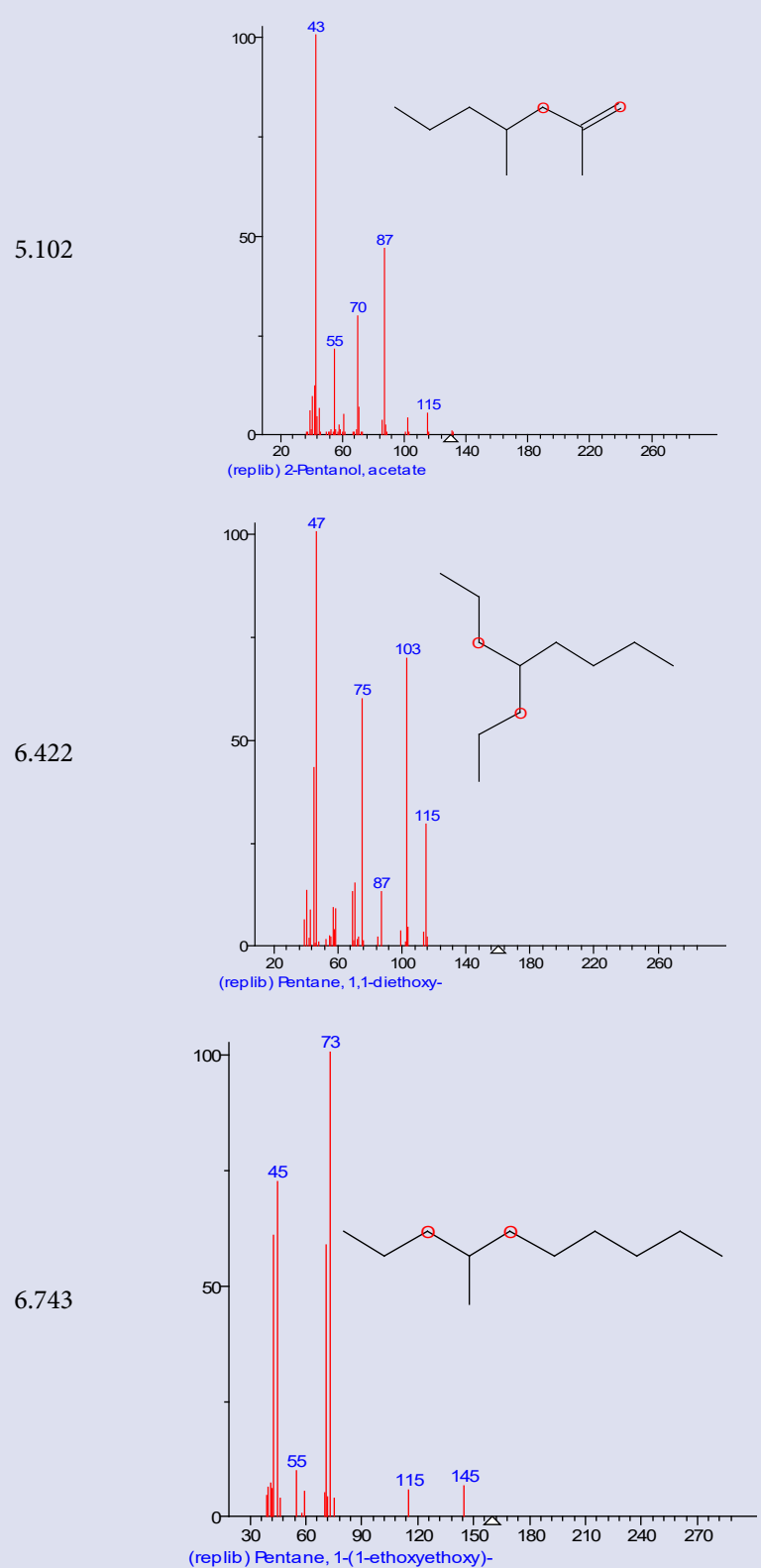

118598 
8<smiles>CCOC(=O)CCC(C)C</smiles>

Valeric acid, 4-methyl-, ethyl ester<smiles>NNC(=O)OCc1ccccc1</smiles>

Benzyl carbazate

10<smiles>NNC(=O)C(N)=O</smiles>

Oxamic acid hydrazide

11

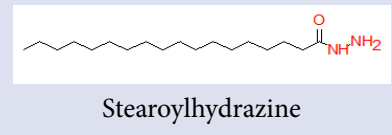

7.183

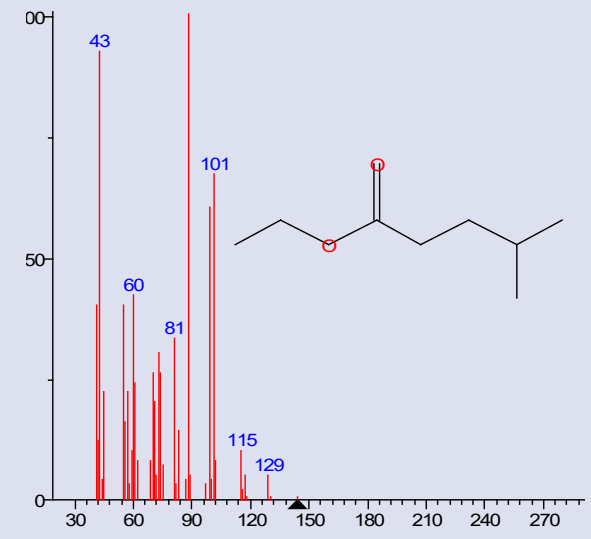

7.980
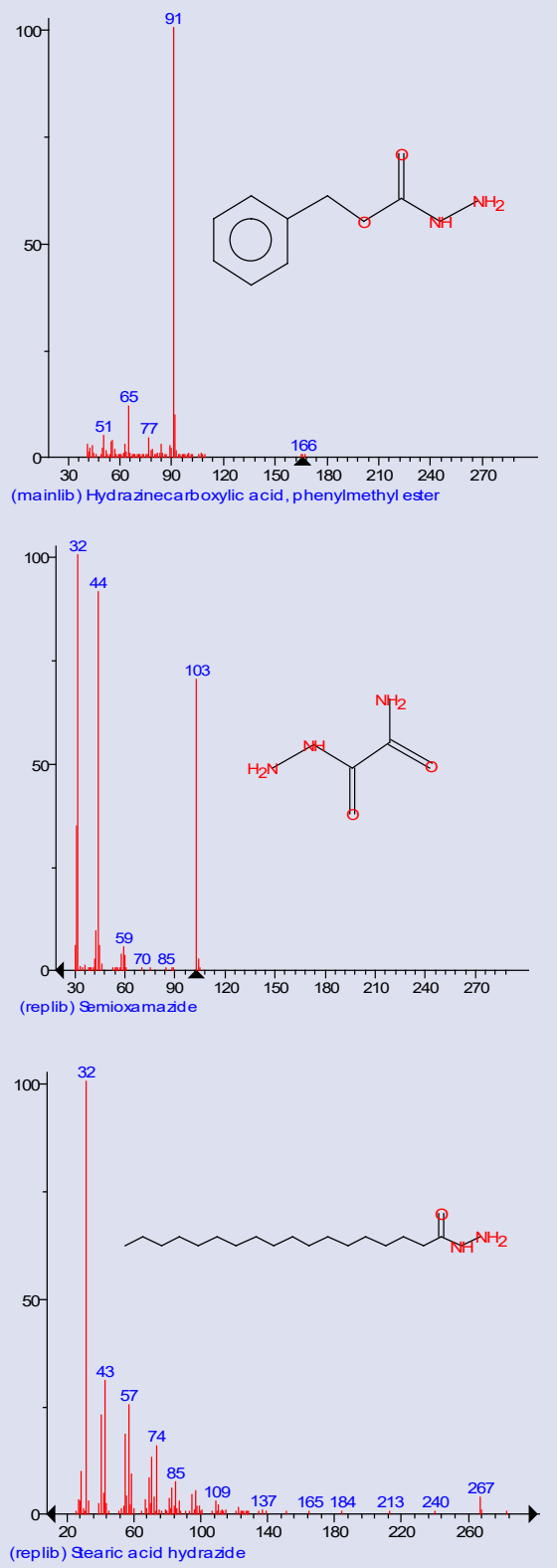

8.485

8.883

(replib) Searic acid hydrazide
69293 
12

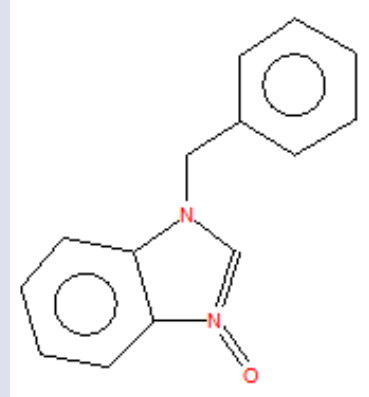

1-Benzyl-1H-benzimidazole 3-oxide

13

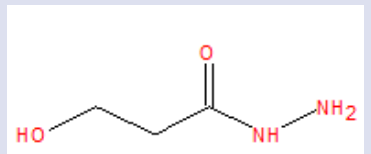

Propanoic acid, 3-hydroxy-, hydrazide

14

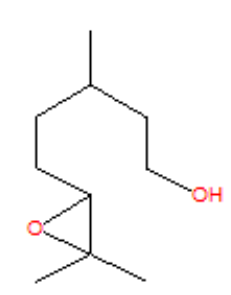

Citronellol epoxide ( $\mathrm{R}$ or S)

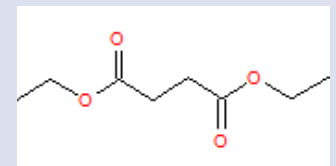

Diethyl succinate
9.109

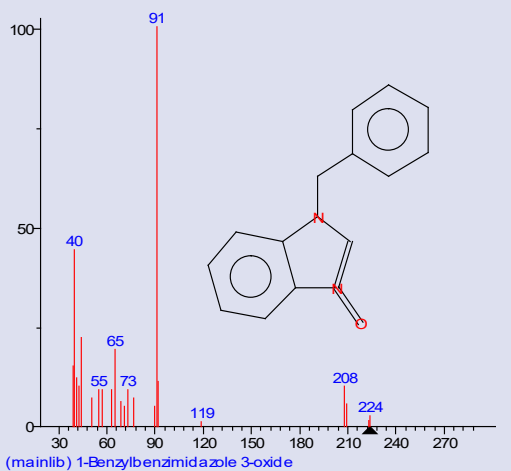

9.621

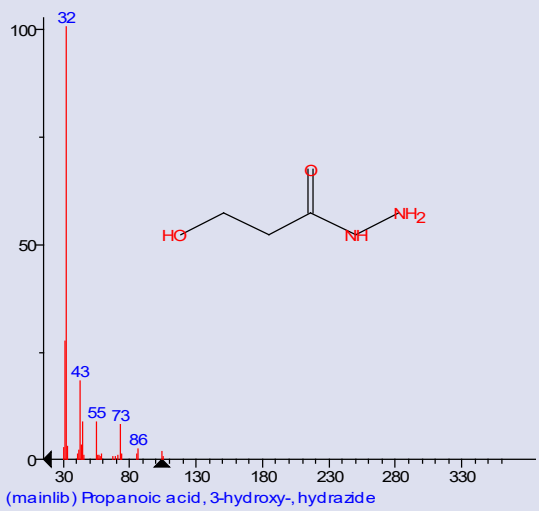

9.954

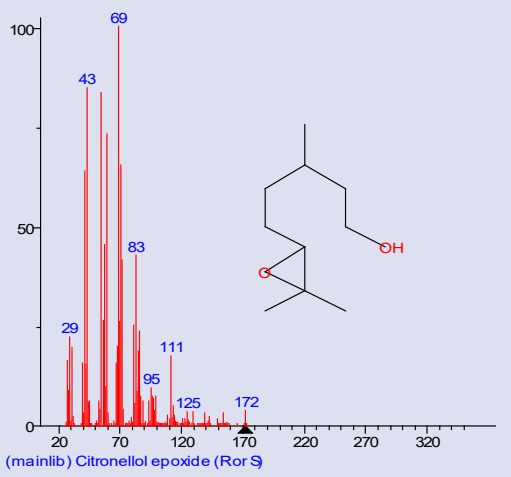

10.073

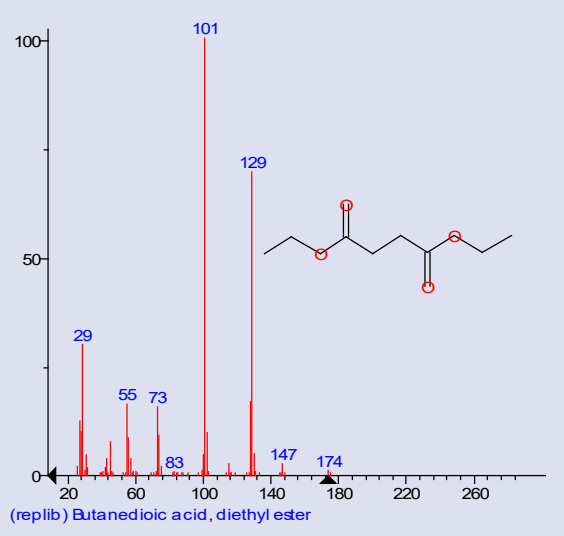

33472

0.76

34513 
16

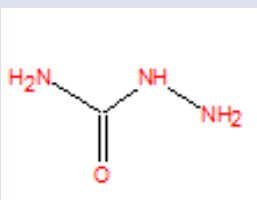

Aminomocovina

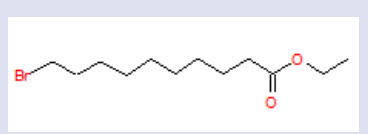

Ethyl 10-bromodecanoate

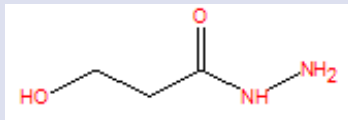

3-Hydroxypropanoic acid hydrazide

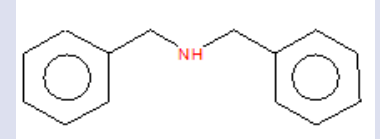

Dibenzylamine

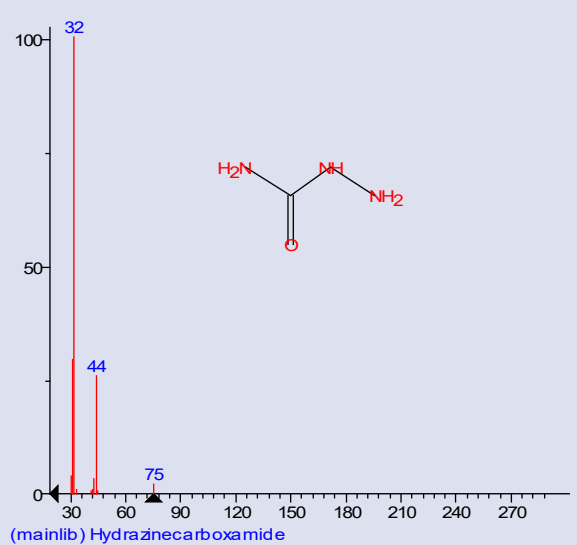

30657

0.70

13.052

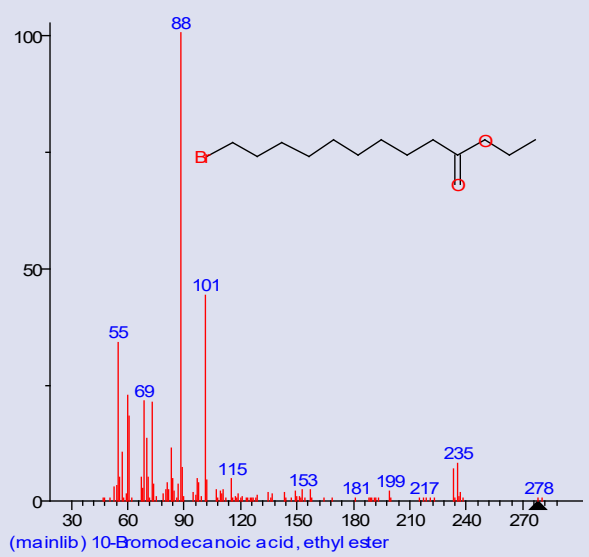

73701

15.745

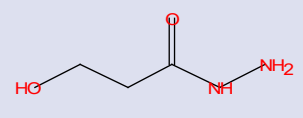

32378

16.340

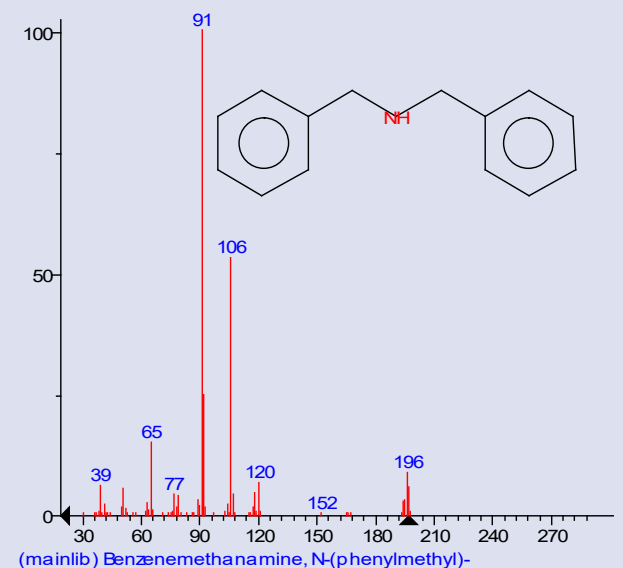

132422 
20

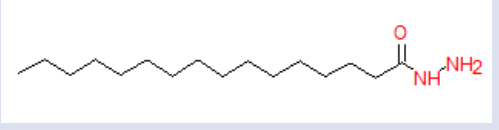

Hexadecanohydrazide

21

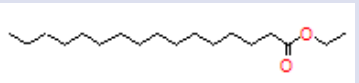

Ethyl palmitate

22

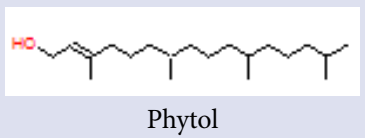

23

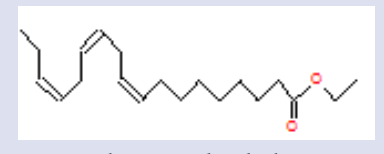

Linolenic acid, ethyl ester
16.756

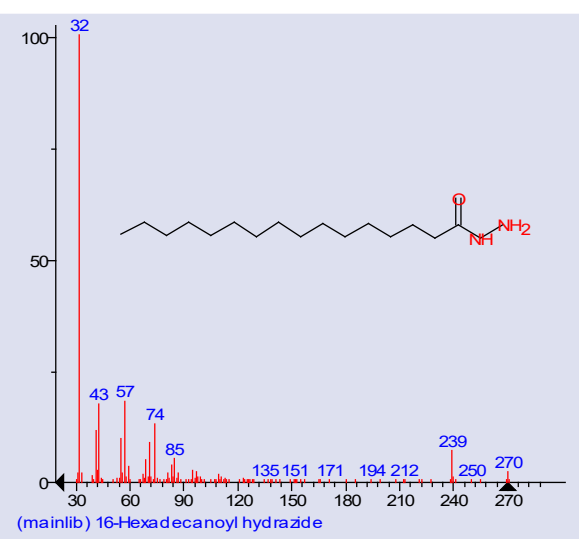

18.177
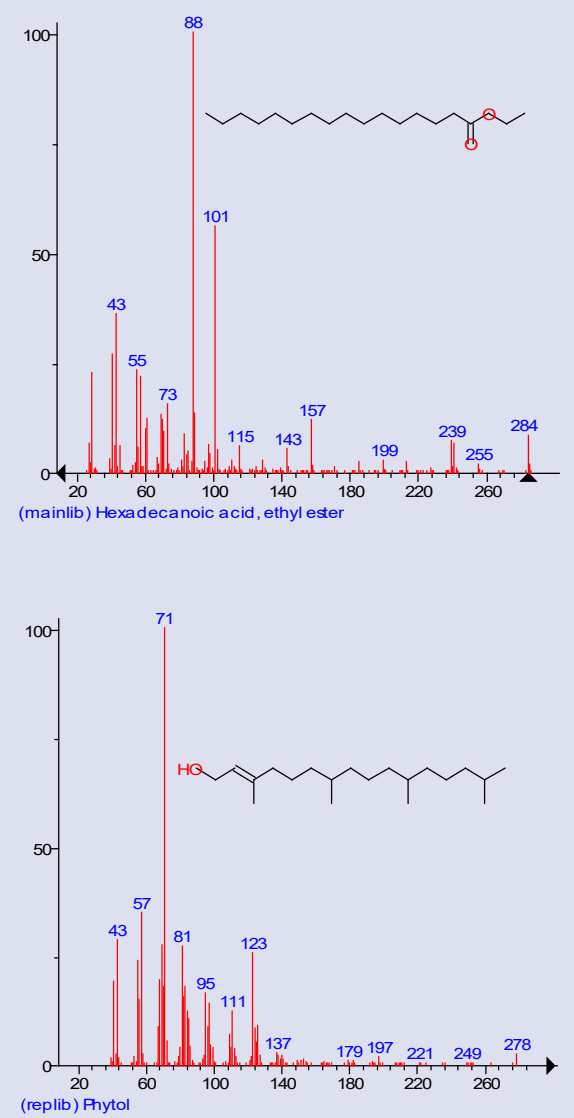

19.325

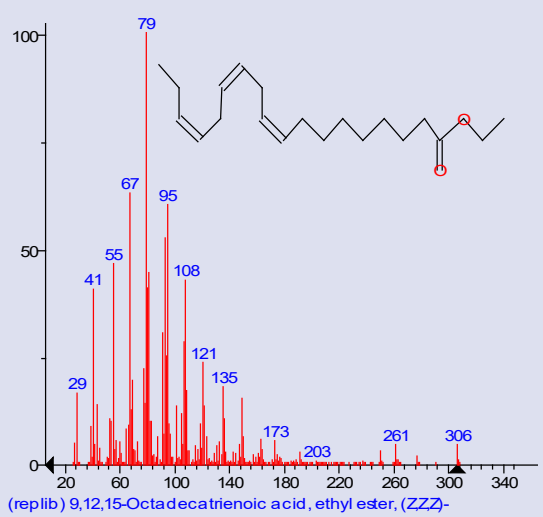

36570

666991 15.18 
24

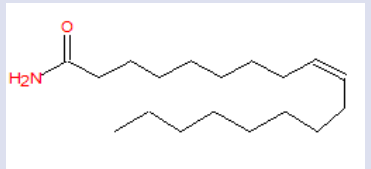

Oleamide

25

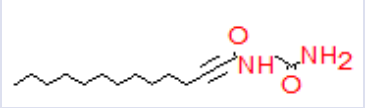

2-Myristynoyl-glycinamide

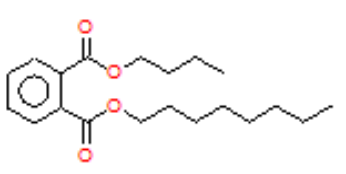

Butyl octyl phthalate

27

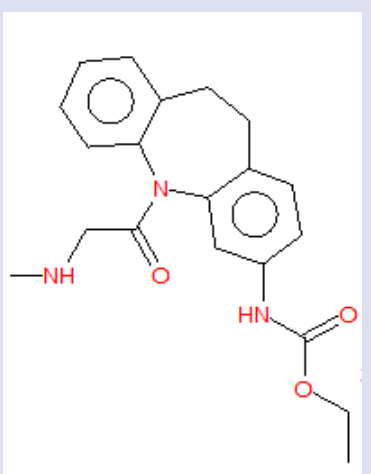

Ethyl 5-[(methylamino)acetyl]-10,11-dihydro$5 \mathrm{H}$-dibenzo[b,f]azepin-3-ylcarbamate
20.466

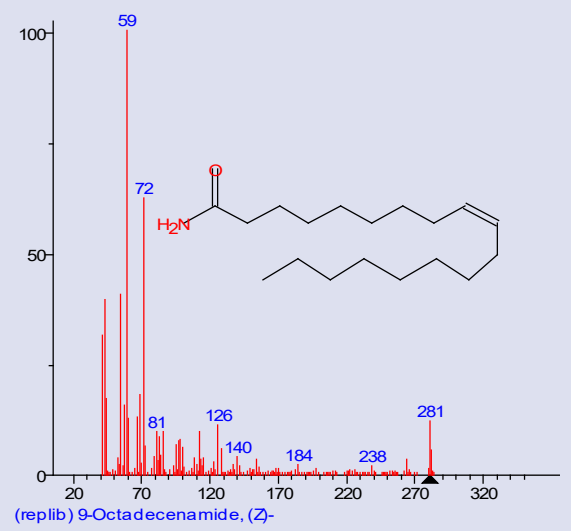

121634

20.591

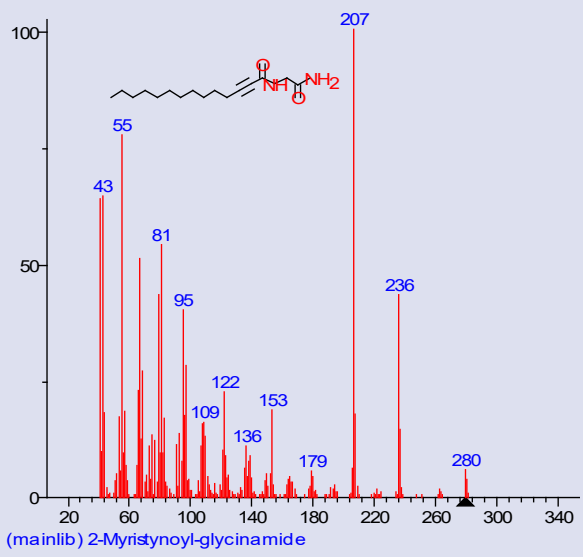

47924

1.09

21.578

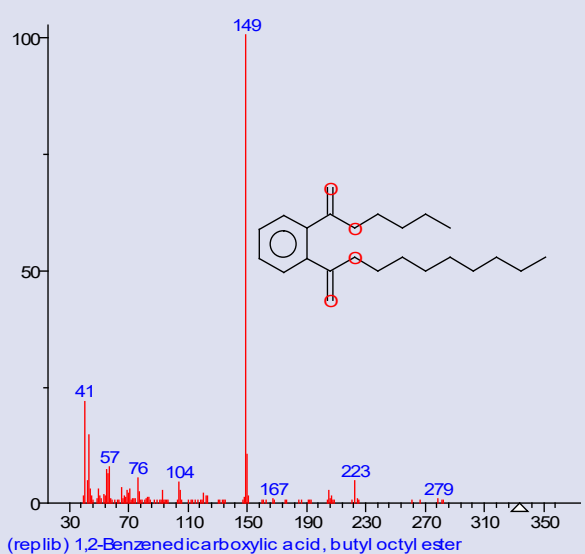

74845

23.308

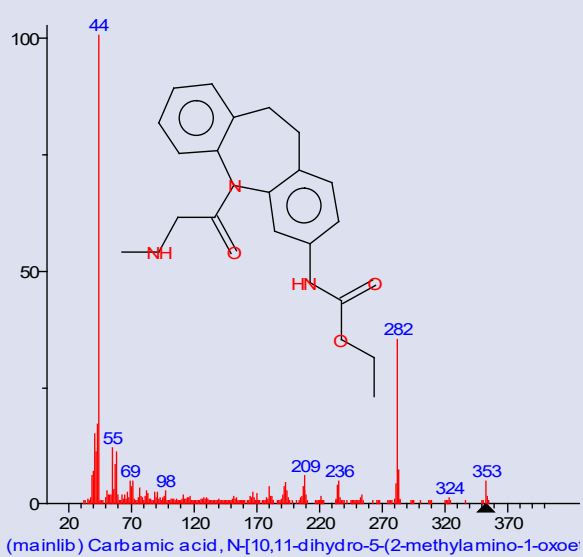

37007

0.84 


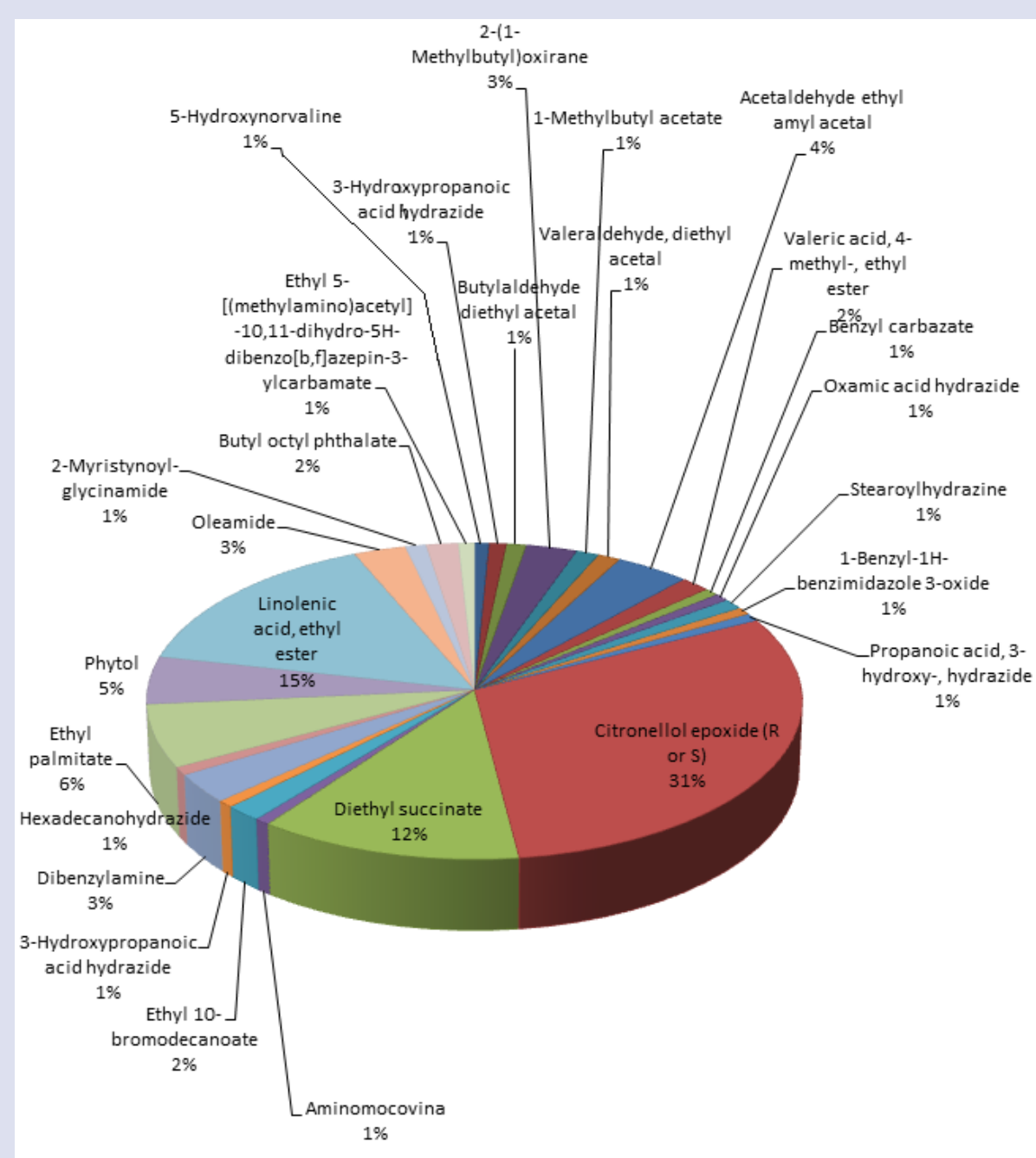

Diagram 1: The compounds identified in alcohol extraction from the Veronica beccabunga $L$.

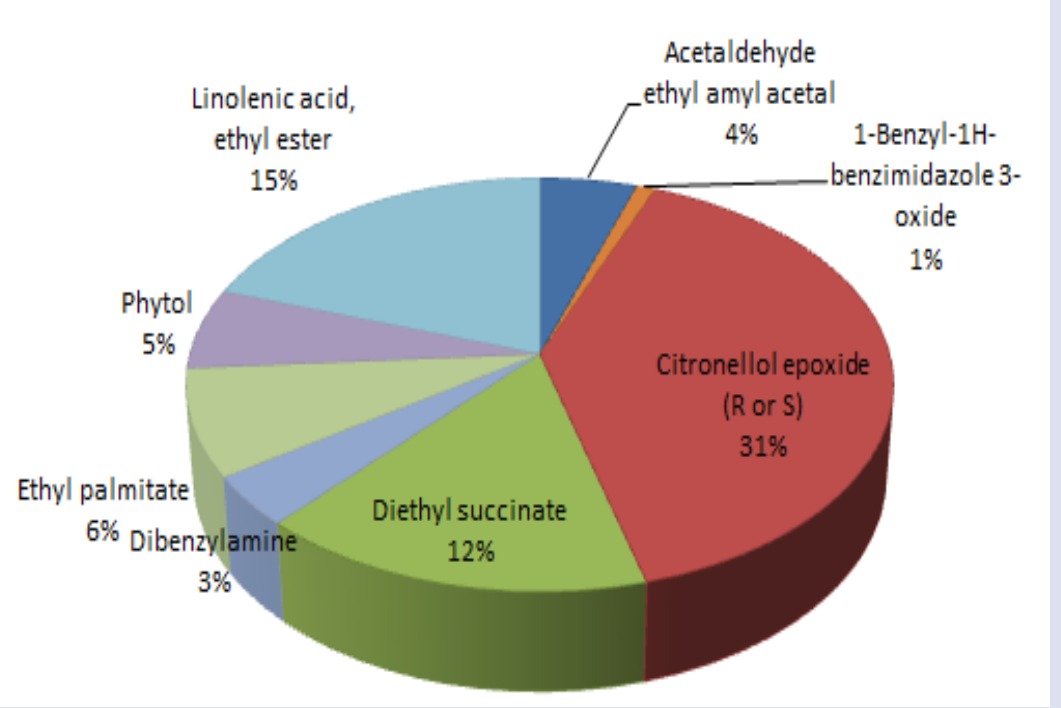

Diagram 2: The main compounds identified in alcohol extraction from the Veronica beccabunga $L$. 


\section{CONCLUSION}

1. The identified morphological and anatomical features of the medicinal herb Veronica beccabunga L. can be used to diagnose this species and develop authenticity indicators for promising medicinal herbs.

2. 27 compounds were identified by chromatography-mass spectrometry. The maximum content falls on: Citronellol epoxide $(\mathrm{R}$ or S) (30.5\%), Linolenic acid, ethyl ester (15.18), Diethyl succinate (12.17\%), Ethyl palmitate (6.43\%), Phytol (4.89\%), Acetaldehyde ethyl amyl acetal (3.94\%), Dibenzylamine (3.01\%), Oleamide $(2.77 \%)$, 2-(1-Methylbutyl)oxirane (2.7\%), Butyl octyl phthalate(1.7\%), Ethyl 10-bromodecanoate (1.68), Valeric acid, 4-methyl-, ethyl ester (1.58). Glycoside detected: 1-Benzyl-1H-benzimidazole 3-oxide (0.76\%)

3. Using the method of simple normalization, the relative percentage of identified compounds was determined.

\section{ACKNOWLEDGMENTS}

Supported by the "Russian Academic Excellence Project 5-100" (Sechenov University).

\section{CONFLICTS OF INTEREST}

The authors declare no conflicts of interest.

\section{REFERENCES}

1. Abd El-Ghani M, Karam M, Abd El-Baky F, Ali R. A taxonomic revision of Veronica sect: Beccabunga in Egypt: confirmation with new additions. Phytol Balc. 2011;16:337-49

2. Abd El-Ghani M, Karam M, Abd El-Baky F, Ali R. Taxonomic relationships in Veronica sect: Beccabunga (Plantaginaceae s.l.) of Egypt: Evidences from morphometric and molecular analyses. Phytol Balc. 2011;17:35-44

3. Antsyshkina AM. On the biological features of the genus Veronica / A.M. Antsyshkina S.G. Zaichikova // V Ros. nat. Congr. "Man and medicine" M., 1998;342-3.

4. Aseeva JIA. Some aspects of the taxonomy of the genus Veronica L. (Scrophulariaceae) / JT. A. Aseeva // International Conference on the Systematics of Higher Plants, dedicated to the 70th anniversary of the birth of V.N. Tikhomirov. M., 2002;9

5. Aseeva LA. Some morphological characters of the corolla of Veronica (Scrophulariaceae) representatives and their significance for the taxonomy of the genus / L. A. Aseeva // Botanical Journal. 2003;87(8):69.

6. Chrtek J, Osbornová-Kosinová J. Veronica sect: Beccabunga in Egypt. Folia Geobot Phytotaxon. 1981;16:423-7.
7. Crisan G, Vlase L, Balica G, Muntean D, Stefanescu C, Paltinean R, et al. LC/ MS analysis of aucubin and catalpol of some Veronica species. Farmacia. 2010;58:237-42.

8. Elenevsky AG. Systematics and geography of Veronics of the USSR and adjacent countries - M .: Nauka, 1978;259.

9. Faten Y Ellmounia, Mohamed A Karama, Refaat M Alia, Dirk C Albach. Molecular and morphometric analysis of Veronica L. section Beccabunga (Hill) Dumort. Aquatic Botany. 2017;136:95-111.

10. Jensen SR, Albach DC, Ohno T, Grayer RJ. Veronica: iridoids and cornoside as chemosystematic markers. Biochem Syst Ecol. 2005;33:1031-47.

11. Maggi A, Taskova RM, Gotfredsen $\mathrm{CH}$, Bianco A, Jensen SR. Chemical markers in Veronica sect. Hebe. III. Biochem Syst Ecol. 2005;37:731-6.

12. Marchant NG. Experimental VeronicaTaxonomy of Veronica Section Beccabunga Griseb. Clare College, University of Cambridge, Cambridge. 1970;263.

13. Meudt HM, Rojas-Andrés BM, Prebble JM, Low E, Garnock-Jones PJ, Albach DC. Is genome downsizing associated with diversification in polyploid lineages of Veronica? Botanical J Linn Soc. 2015;178:243-66.

14. Müller K, Albach DC. Evolutionary rates in Veronica L. (Plantaginaceae) Disentangling the influence of life history and breeding system. J Mol Evol. 2010;70:44-56

15. Munoz-Centeno LM, Albach DC, Sánchez-Agudo JA, Martínez-Ortega MM. Systematic significance of seed morphology in Veronica (Plantaginaceae): A phylogenetic perspective. Ann Bot. 2006;98:335-50.

16. Öztürk A, Fischer MA. Karyosystematics of Veronica sect: Beccabunga (Scrophulariaceae) with special reference to the taxa in Turkey. Plant Syst Evol. 1982;140:307-19

17. Pereira JA, Oliveira I, Sousa A, Valenta o P, Andrade PB, Ferreira ICFR, et al. Walnut (Juglans regia L.) leaves: Phenolic compounds, antibacterial activity and antioxidant potential of different cultivars. Food and Chemical Toxicology. 2007:45:2287-95.

18. Savinykh NP. On homologs in the shoot systems Veronica L (Scrophulariaceae) / N.P. Savinykh. SPb: St. Petersburg. union of scientists. 2001;332.

19. Schlenker G. Systematische Untersuchungen über die Sektion Beccabunga de Gattung Veronica. Repertorium specierum novarum regni vegetabilis. Beihefte. 1936;90:1-40.

20. Sellers RF. Morpho-geographical Analysis of Veronica Section Beccabunga University of Oklahoma, Norman. 1983;58

21. Søren Rosendal Jensen, Sebastian EdWieland Opitz, Charlotte Held Gotfredsen. A new phenylethanoid triglycoside in Veronica beccabunga L. Biochemical Systematics and Ecology. 2011;39(3):193-7.

22. Swiatek L. Pharmacobotanic studies on some species of the family Scrophulariaceae: Phytochemical analysis of Veronica beccabunga L / L. Swiatek // Diss, pharm, et pharmacol PAN. 1968;20(5):543.

\section{GRAPHICAL ABSTRACT}

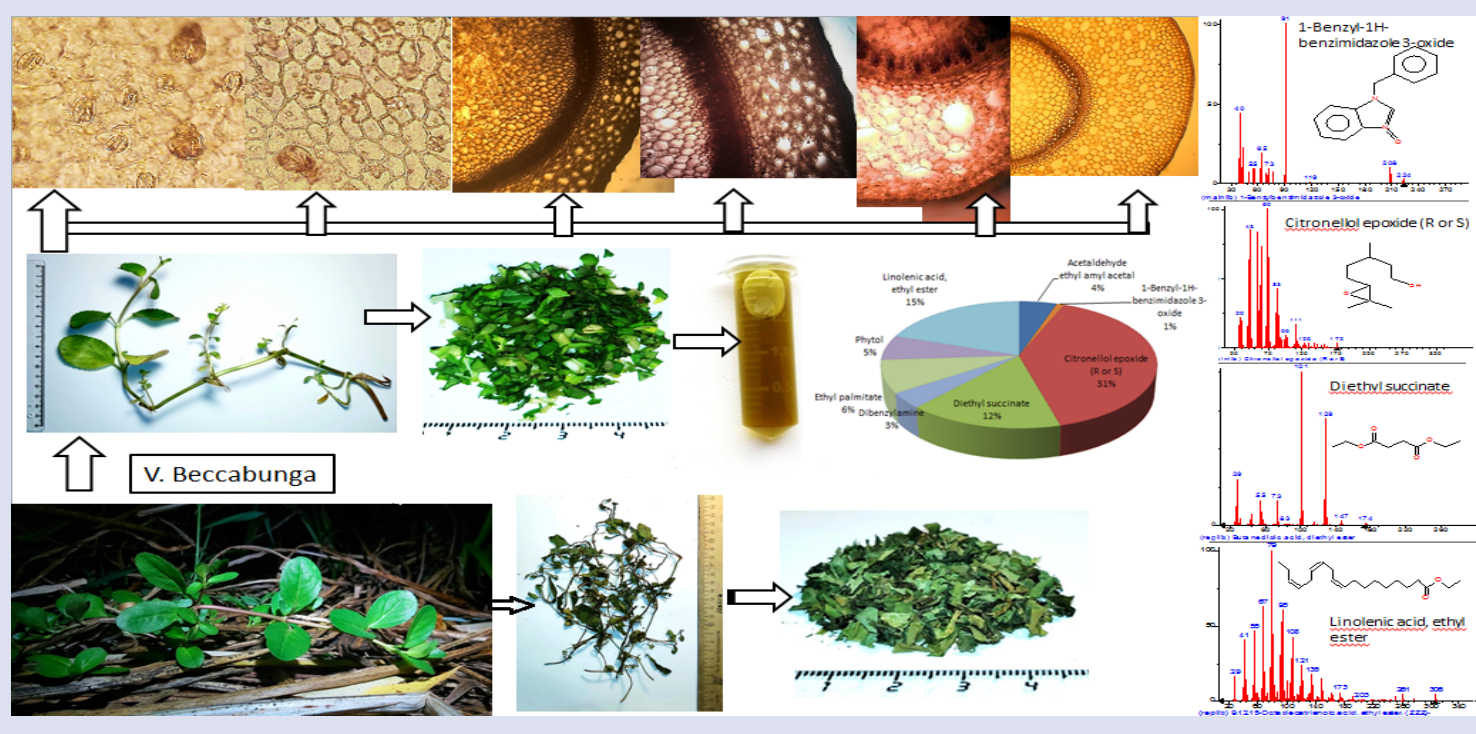




\section{ABOUT AUTHORS}

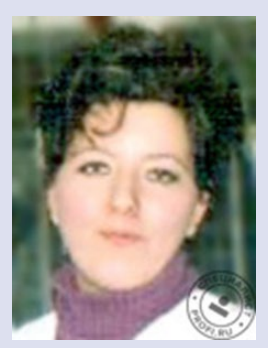

Strelyaeva Angelina Vadimovna: is doctor of Pharmaceutical Sciences, Professor of Department of Pharmaceutical Natural Sciences, I.M. Sechenov First Moscow State Medical University.

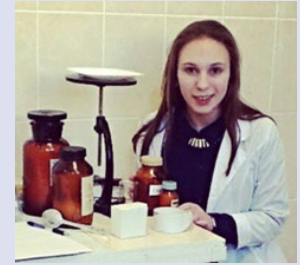

Larina Olga Alekseevna: 3rd year student, Institute of Pharmacy, I.M. Sechenov First Moscow State Medical University.

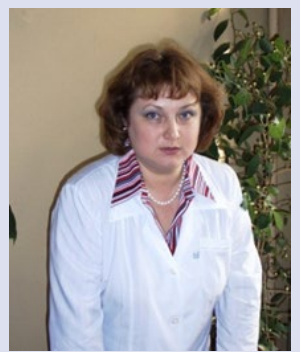

Antsyshkina Alla Mikhailovna: is candidate of Pharmaceutical Sciences, Associate Professor of Department of Pharmaceutical Natural Sciences, I.M. Sechenov First Moscow State Medical University.

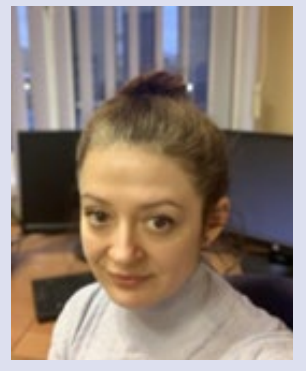

Kuznetsov Roman Mikhailovich: is leading researcher, Laboratory of Pharmacokinetics and Metabolic Analysis, I.M. Sechenov First Moscow State Medical University.

Bondar Alina Alexandrovna: is candidate of Pharmaceutical Sciences, Associate Professor of Department of Pharmaceutical Natural Sciences, I.M. Sechenov First Moscow State Medical University.

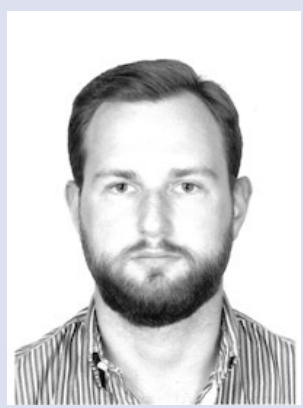

Sorokin Vladimir Alexandrovich: is assistant of Department of Pharmaceutical Natural Sciences, I.M. Sechenov First Moscow State Medical University.

Cite this article: Strelyaeva AV, Larina OA, Antsyshkina AM, Kuznetsov RM, Bondar AA, Sorokin VA. The Study of External Signs, Microscopy and Chemical Composition of Medicinal Plant Materials of Veronica beccabunga L. Herb. Pharmacog J. 2020;12(2):391403. 